\title{
Popular Development Economics-An Anthropologist among the Mandarins
}

\author{
Mike McGovern
}

\begin{abstract}
The Bottom Billion: Why the Poorest Countries Are Failing and What Can Be Done about It. By Paul Collier. New York: Oxford University Press, 2007. 224p. \$35.00 cloth, \$15.95 paper.

Wars, Guns, and Votes: Democracy in Dangerous Places. By Paul Collier. New York: Harper Perennial, 2009. 272p. $\$ 26.99$ cloth, \$14.99 paper.
\end{abstract}

n n 1997, I found myself newly arrived at Oxford University. I was taking a detour from my path to do research in West Africa thanks to a fellowship that funded a year of ancillary training before my fieldwork. Though studying anthropology, I was at St. Antony's College, where Paul Collier's Center for the Study of African Economies is located, and was in the same entering cohort as Collier's now-famous student Dambisa Moyo (assuming I would not be able to remember her first name, she offered, "it sounds kind of like 'pizza").

During my first week there, I was talking with three graduate students in development economics and asked them whether the 1997 Asian economic crisis had caused development economists to question any of their models. Yes, they assured me, the crisis had left them and the field more generally rather shaken and ready to entertain all kinds of new ideas about how economies work. I found that interesting and, telling them that I worked in Africa, asked whether the failure of African economies to conform to most economic models caused them similar consternation. All three replied simultaneously with a derisive snort and chuckles, followed by assurances that no, Africa's failure to develop was not challenging economic theory then or any time soon.

I assume these were not students of Paul Collier, an economist who has dedicated his career to understanding how African economies do work. But the vignette is perhaps instructive inasmuch as it gives a sense of how economists, even development economists, tend to view Africa. Where Africa and economic theory fail to coincide, the fault lies squarely with Africa, not with economic theory.

In his books The Bottom Billion: Why the Poorest Countries Are Failing and What Can Be Done about It and Wars,

Mike McGovern is assistant professor of anthropology at Yale University.
Guns, and Votes: Democracy in Dangerous Places (cited henceforth as BB and WGV, respectively), Collier attempts to bring African and other poor countries with problems of "stuck" development back into the conversation of economists, policymakers, and an educated nonspecialist readership. Book cover testimonials from The Economist, Larry Summers, Larry Diamond, and New York Times columnist Nicholas Kristof give a sense of the readership Collier has targeted. Using analysis based on econometric studies he has conducted with his research colleagues at Oxford and the World Bank, he first tries to make sense of the world's "basket cases," and then to propose policy interventions that may help them to set themselves right.

Collier's argument starts from the finding that the bottom billion have stagnated over the past forty to fifty years while the other four billion people living in the "developing world" have not only achieved economic development but, in most cases, a greater degree of political stability. He identifies four "traps" that reinforce economic stasis, political instability, and each other. They are conflict, reliance on natural resources, being landlocked with bad neighbors, and bad governance. Having laid out these structural challenges, Collier uses the second half of The Bottom Billion to outline some possible solutions, including judicious use of development aid, postconflict international peacekeeping missions, revised international laws that would diminish the complicity of richer governments and their businesses in bad governance and conflict, and revising trade policy in a way that actively favors the poorest countries.

In Wars, Guns, and Votes, Collier goes further, elaborating his theory of how electoral democracy feeds instability, especially in a context where countries are "too diverse for cooperation to produce public goods" (BB: p. 9), guns are easily available, looting easy, and a past history of coups has weakened democratic culture and emboldened the military. In this book, his proposed solution is more activist: 
he proposes that poor countries be invited by rich countries to sign a kind of promissory note to abide by democratic principles and practice. For as long as they continue to do so, the rich countries will provide an "over the horizon" guarantee against rebellion and coup d'état. If they fail to respect their engagements, the rich countries will effectively call off their promise of protection, implicitly inviting the national military to punish the antidemocratic leaders of poor countries with a coup. The putschistes themselves would then be invited to sign on to the good governance pact, promising quick and transparent elections, and the game would begin anew. ${ }^{1}$ This essay evaluates Collier's core arguments and the evidence presented in support of them, while trying to make a series of observations about the stakes involved for social scientists (including though not limited to political scientists) who work on issues of conflict, development, ethnicity, and the other topics Collier takes up.

As a sociocultural anthropologist who has worked in Guinea, Côte d'Ivoire, and Liberia over the past twenty years, the places and problems Collier describes are familiar to me. As a former West Africa director of the International Crisis Group who used to brief the UN Security Council and who has done advocacy with or worked alongside the African Union, UN agencies, the World Bank, the European Union, and other actors in conflict, peacekeeping, and postconflict reconstruction settings, I have a slightly different (and probably more sympathetic) view of Collier's undertaking than some of my anthropological colleagues. The predictable ethnographic veto- "That's not how they do it in my village!"- - one might expect from an anthropologist is thus not my point of entry in reading these books. As someone sympathetic to both the possibilities and risks of putting rigorous academic analysis into conversation with policy initiatives in high-stakes environments, I would suggest that such hybrids are only as good as their results. Thus, not only do I welcome Collier's books and others like them, I also freely admit that one of the only disciplines less successful than development economics in forging a successful hybridization of theory and practice is my own.

What is striking to me as an anthropologist, however, is that much of the fundamental intellectual work in Collier's analyses is, in fact, ethnographic. Because it is not done very self-consciously and takes place within a larger econometric rhetoric in which such forms of knowledge are dismissed as "subjective" or worse still biased by the political (read "leftist") agendas of the academics who create them, it is often ethnography of a low quality. Sometimes the ethnographic insights are just implied (but deducible from a close reading of the links suggested between correlations and causality), and, at other times, undertaken via passing anecdotes or ventriloquized descriptions of the motivations and states of mind of the members of the bottom billion. What follows is thus my attempt at an ethnography of the world-imaginative, discursive, but also technical and action oriented-of Paul Collier and, by extension, of the broader genre of popular economics, from Freakonomics to Dead Aid. ${ }^{2}$ Among my central questions are how Collier imagines poor people to interact in social settings, and why his often bold theories about conflict, development, and politics have garnered a sizeable general audience. How might we better understand the itch among those readers of the New York Times, the Guardian, Le Monde, and The Economist that Collier, Jeffrey Sachs, and others (including various rock stars) aspire to scratch?

I suggest that too often these books are more about "us" than "them." Despite the adoption of a Naipaulian unsentimental-dispatches-from-the-trenches rhetoric, the story told in Collier's two books is in the end a morality tale. The tale is about those countries and individuals with the gumption to pull themselves up by their bootstraps or the courage to speak truth to power, and those powerdrunk bottom billion elites, toadying sycophants, and softhearted academics too blinded by misplaced utopian dreams to recognize the real causes of economic stagnation and civil war. By insisting on the credo of "just the facts, ma'am," the books introduce many of their key analytical moves on the sly, or via anecdote. What an anthropological approach to these same questions would insist on is the attempt to see the dynamics of bottom billion politics and economics through the actors' points of view. This attempt has the positivist objective of fact checking both one's facts and one's categories of analysis, so as to be sure that there is some semblance of fit between the motives, incentives, and rationales attributed to actors and those they may actually be using. Collier expresses disdain for such attempts as a kind of misplaced humanism that is easily manipulated by greedy dictators in search of "useful idiots." However, it is precisely the epistemological solipsism of his morality tale that exposes its greatest analytical weaknesses at the same time that it best explains why it appeals to a broad audience that has genuine interest in understanding suffering in poor countries even while it has little interest in having its sense of its own well-merited success questioned. This is one explanation of how he comes to the point of effectively arguing for an international regime that would chastise undemocratic leaders by inviting their armies to oust them-a proposal that overestimates the virtuousness of rich countries (and poor countries' armies) while it ignores many other potential sources of political change, such as those sweeping North Africa as I make the final revisions to this essay.

\section{Two Kinds of Iconoclasm}

Part of my own research focuses on the destruction of ritual objects by the newly independent West African 
state of Guinea. Such iconoclasm was a tool of this selfconsciously modernizing state to do away with the embarrassing practices of a polytheistic past. National elites prioritized this purge as Guinea claimed its place on the world stage in a context where many questioned the ability of African nations to govern themselves. Sociologist of science Bruno Latour has suggested that many scientists operate with an iconoclastic model of the creation of knowledge. ${ }^{3}$ For those of us who study the often-violent policies that have aimed to destroy actual objects and the ways of life they are seen to represent, this metaphorical use of the term "iconoclasm" can sometimes seem strained. Yet in reading Collier's writing, it is undeniable that he underlines the boldness of his claims as well as the quality of his evidence in explicitly iconoclastic terms. Consider this passage from the preface to The Bottom Billion:

Our notions about the problems of the poorest countries are saturated with such images [as that of Che Guevara]: not just of noble rebels but of starving children, heartless businesses, crooked politicians. You are held prisoner by these images. While you are held prisoner, so are our politicians, because they do what you want. I am going to take you beyond images. Sometimes I am going to smash them. And my image smasher is statistical evidence. (BB: xii)

Throughout his popular books, Collier strikes the pose of a kind of true-life Indiana Jones, one who does research in and on dangerous places, and who has to fight the oppressive status quo of academic researchers and other do-gooders who argue from politically correct hunches and a priori biases. He portrays himself as bucking the received wisdom on development and conflict, and even says he surprises himself with the results of his rigorous quantitative analysis. In a New York Times Book Review essay, Niall Ferguson wrote, "Collier is the authentic old Africa hand: he knows the terrain and has a keen ear." 4 But he is an old Africa hand who wields the powerful weapon of modern statistics. He is also self-critical enough to see himself in the sights of other would-be iconoclasts. At the end of Wars, Guns, and Votes, he notes that "academics fight a zero-sum game over reputation in which the fast route to success is to demolish some prominent piece of work" (WGV: p. 235).

My aim in this essay is not to demolish Collier's important work, nor to call into question development economics or the use of statistics. Many others have done a better job of exploring the emergence and growing power of statistics in the "low sciences" than I could. ${ }^{5}$ But the rhetorical tics of Collier's books deserve some attention. They are filled with phrases like "You might expect that democracy is at its most useful for the economy when there are lots of natural resources around. You might think so, but you would be wrong" (BB: p. 42). Combined with his frequent references to academics who disagree with him as being "politically motivated" (BB: pp. 18-19), Collier con- sistently constructs his audience as ignorant. While the public at large is simply ill informed and occasionally misled, his imagined academic and NGO adversaries are cast as willfully resistant to the facts.

This might be just a rhetorical style, one that is evidently a winning one with an audience that is aware that fifty years of development policy has failed in the parts of the world where the bottom billion live. However, it does raise two substantive questions for Collier's own analysis. The first is that if his European and North American audiences are so deeply (and, it would seem, so easily) misled, why is he quick to presume that the "bottom billion" are rational actors? Mightn't they, too, be resistant to the good sense purveyed by economists and other demystifiers?

The other is that the self-assuredness of economists such as Collier may be a part of the problem and not, as they suppose, a part of the solution. For an outsider, the strangest thing about the field of economics is the fact that although it appears to be wrong much of the time, rather than becoming chastened and introverted, most of its practitioners seem to become bolder, drawing strength from their failures as the mythological Antaeus did by touching the ground. Though Collier as iconoclast writes as if prior development policies have been mired in preconceived notions and misplaced sympathy, the advocates of those same policies also thought that they were acting on the basis of sound data that did away with the misrecognitions that had mystified their predecessors. Looked at over the fifty-year span since the publication of W. W. Rostow's The Stages of Economic Growth: A Non-Communist Manifesto, development economics as a field looks far more like literary criticism than like those natural sciences it emulates. ${ }^{6}$ As we contemplate the series of enthusiasms that have characterized different moments in development theory and policy, it looks an awful lot like movements from romantic to symbolist to modernist to beatnik poetry. We may not yet have seen beatnik development economics, but we can still hope!

The difference between poets and economists, however, is that for poets, as for literary critics, there are rivalries and certainly individual claims to preeminence, but as a general rule, there is an acceptance that there are many ways to write a great poem, just as there are many enlightening ways to read any great poem. Bound as it is to the model of the natural sciences, economics cannot accept that there might be two incommensurable but equally valuable ways of explaining a given group of data points. Objectively speaking, this is what happens. Paul Collier, William Easterly, and Jeffrey Sachs can all be tenured professors and heads of research institutes, despite the fact that on many points, if one of them were definitively right, one or both of their colleagues would have to be wrong. If economics really were like a natural science, this would not be the case. 


\section{Witchcraft, Oracles, and Regressions}

My approach here is to regard numbers, graphs, and formulas first of all as strategies of communication. They are intimately bound up with forms of community, and hence also with the social identity of the researchers.

Theodore Porter, Trust in Numbers: The Pursuit of Objectivity in Science and Public Life

Portions of the two books draw on Collier's academic articles to show one or several intriguing correlations. Having run a series of regressions, he identifies counterintuitive findings, like the following: Low income per capita correlates strongly with the onset of civil war, while unequal income distribution does not. There is no "Africa effect": poor countries subject to the four traps he describes (conflict, natural resource reliance, being landlocked, bad governance) behave in broadly similar ways, whether they are found in Africa (about 70 percent of the bottom billion) or elsewhere. When aid surpasses 16 percent of GDP, it ceases to aid development. High levels of military spending by postconflict countries correlate to an increase rather than a decrease in the chances of reversion to conflict.

However, his analysis is typically a two-step process. First, he states the correlation, and then, he suggests an explanation of what the causal process might be. Sometimes, he is cautious about supplying this guess about why certain correlations exist. He writes, "as usual with aid, we faced the problem that causality can run in both directions" (BB: p. 113), and, "So if low income and slow growth make a country prone to civil war, it is reasonable to want to know why. There could be many explanations. My guess is that it is at least in part because low income means poverty, and low growth means hopelessness" (BB: p. 20).

At other times, he either fails to add such important caveats or, in fact, does not even add a second step to the explanation, allowing the correlation to stand as if its link to causation were self-evident. Much of the intellectual heavy lifting in these books is in fact done at the level of implication or commonsense guessing. And the common sense is surely not that of the inhabitants of the countries being dissected, but that of the highly educated elite located primarily in Western Europe and North America. In those passages where Collier does lay out the thinking behind his explanations, they are always coherent and plausible, but the chain of causal relations makes it evident how fragile these models typically are. For example, after showing that increased military spending by postconflict governments correlates with a higher incidence of further conflict, he gives a rare exposition of the explanatory chain that lies behind his argumentation:

We have an idea of what has gone wrong, and it involves time inconsistency. In postconflict situations neither side trusts the other. The rebels face the greater problem because governments can maintain their armies during peace much more easily than can rebels. So although the government has an incentive to promise an inclusive peace deal, as time goes on it has less and less of an incentive to keep its word. As a result, there are sure to be factions among the rebel forces wanting to go back to war preemptively, while the option is still open. High military spending by the government may inadvertently signal to rebel forces that the government is indeed going to renege on any deal and rule by repression. (BB: 132)

It is hard to know what to make of this complex and involved scenario. Is it an ideal-typical composite, meant to stand in for the particularities of any case? Are all cases meant to display at least some of the dynamics described here? What difference does it make if some elements are shown to be invalid for a particular case? Though it would be churlish to pick this passage apart phrase by phrase, I can think of counterexamples from recent African conflicts for almost every assertion. Perhaps the most obvious is the assertion that rebel groups cannot maintain their forces as well as national armies, contradicted by numerous rebel groups from the Casamance to the Sahara to northern Uganda to eastern Democratic Republic of Congo.

The broader point is that while sophisticated statistical manipulations can yield exciting new avenues of research, assigning causal significance in complex interactions such as war or development is ultimately going to come down to discernment and judgment, whether one owns up to that fact or not. I personally find many of Collier's analyses highly plausible, and some of his policy recommendations appear sound, at least for certain places and times. However, that does not exonerate him from critique, especially given the iconoclastic rhetorical stance he has chosen. The typical criticism of qualitative social science by people who work with statistics is that their analyses are "anecdotal" and "impressionistic." I agree, but would add two caveats: first, not all impressions are equal. Some, based on long-term familiarity with a place, its history, its politics, and the ways that people arrive at evaluations of the world around them, have a reasonable chance of yielding useful analytical insights over the medium term. Others may well be little more than projections of the observer's own particular view of the world, and we may find out more about his or her biases than about the society in question when he or she begins to remark on what he or she finds strange or significant in another setting. ${ }^{7}$ It is such unreliable "subjective" bias that economists presumably hope to avoid in sticking to the numbers, yet what I find striking in many works of cross-cultural economic analysis is the casualness of the analytical moves from correlation to causality. In other words, I agree with Collier about the unreliability of "subjective" analysis. I just think his economist colleagues are often more guilty of it than we qualitative types. 
A few examples are in order. After demonstrating correlations between low per capita income and civil wars (as well as coups), between a history of wars (or coups) and their recurrence, and between slow growth and the onset of civil war, what does he do? At one point, while summarizing Jeremy Weinstein's work on rebel group recruitment in Mozambique and Sierra Leone, he lapses into an imaginary account of would-be rebels's states of mind:

Others will be attracted by the prospects of power and riches, however unlikely; if the reality of daily existence is otherwise awful, the chances of success do not have to be very high to be alluring. Even a small chance of the good life as a successful rebel becomes worth taking, despite the high risk of death, because the prospect of death is not so much worse than the prospect of life in poverty. (BB: 29)

How do we know these things to be true? They must either come from conversations with the fighters themselves, a type of source that is usually excluded from Collier's account (remember the passage about misleading "images," quoted above), or from the author's own imagination. There are many aspects left unexplored, and no justification given for privileging one explanation over another. In Liberia, Sierra Leone, and Côte d'Ivoire, some young men joined "prophylactically," trying to protect their home communities from attack. Others joined one militia group to avenge the deaths of loved ones at the hands of that group's enemies. Others, including some women, joined by their own accounts partly for the fun and adventure of being fighters. ${ }^{8}$

Collier concludes that "gradually, the composition of the rebel group will shift from idealists to opportunists and sadists" (BB: p. 30). This may be true in some cases, but most analyses based on extended field-based research of fighting units (including those of industrialized countries) tend to conclude that there are endogenous factors at work, and that the ethos and practices of fighting units change over time in reaction to the situations the fighters meet. Such dynamics are complex, and those of us who study them in a small number of cases tend to derive quite different patterns from our data than the patterns that show up in large-N studies like Collier's. In the most benign scenario, this may simply be a matter of perspective, and both explanations may be true. However, it may also be a case of misrecognition. ${ }^{9}$ This is certainly the impression one has when Collier makes his bolder statements, such as, "Because Africa is the epicenter of low income and slow growth, it has become the epicenter of coups" (BB: p. 36). Why not the other way around? It would be interesting to know whether Collier understands these analytical strategies as unfortunate slips, sleight of hand, or perfectly justified, given the sound basis of the initial statistical inferences. To an outsider, the system of argumentation looks much like that of Azande witchcraft and divination as famously described by E. E. Evans-Pritchard. ${ }^{10}$ Once one has accepted a small number of first principles, the system remains internally coherent and can account for most forms of contradictory evidence.

\section{The Stakes for Political Science}

This is why these issues are so significant for the field of comparative politics, for instance. How do we know which differences between cases are politically significant, and which are epiphenomenal? How can we isolate independent variables correctly? As I write this, the two countries in which I do most of my research, Côte d'Ivoire and Guinea, have just finished electoral cycles. Both are firmly in the bottom billion by Collier's definitions. In both countries, first-round elections went smoothly, but secondround elections caused political and ethno-regional tensions to increase. However, in Guinea, the highly contested result eventually held and the country averted mass violence at least for the near future, while in Côte d'Ivoire, the elections reignited all of the splits that had fuelled the preelection partition of the country, and the situation seems to be heading inexorably toward large-scale violence.

How do we explain the difference between these very different outcomes in two neighboring countries, both ex-colonies of France, with shared geoclimactic conditions and even partially shared ethnic populations? Both countries exhibit most of Collier's traps: resource curses, poor governance, bad neighborhood, and in both cases large-scale violence that didn't (or in the Ivorian case, barely) rose to the level of war. It seems to me that little in Collier's model can help us. If it would predict civil conflict in Côte d'Ivoire, it can't help explain the lack of it in Guinea. Moreover, it is nowhere near a fine enough instrument to tell us why the incipient war in Côte d'Ivoire has never yet really taken off.

I shall discuss Collier's own treatment of the Ivorian case below, but here I want to simply underline some points made by political scientists themselves about other approaches to understanding the causes of political violence. One, indicated by the comparison of Guinea and Côte d'Ivoire, is that there is an inherent selection bias in work like Collier's because the model is built from existing cases of warfare, and thus tends to render counterfactual cases invisible. Places like Guinea, Tanzania, Ghana, and Senegal consequently don't come in for much discussion while Chad, Sudan, Afghanistan, CAR, and the DRC do. ${ }^{11}$

Second, the nation remains the unquestioned unit of analysis throughout Collier's studies. The work of my colleagues Stathis Kalyvas, James Scott, and Elisabeth Wood all show in different ways how subnational differences can be far more important than cross-national ones. ${ }^{12}$ Returning to the Ivorian case, the level of violence in the country's far west region has been an order of magnitude higher than in the other regions over the past decade. It takes me several chapters in my own book on the Ivorian conflict to 
explain this. This is because it results from particularities of the political economy of a cocoa plantation frontier zone, the history and demographics of long-term internal colonization of the region, and the political entrepreneurship of specific individuals who capitalized on these structural possibilities in order to benefit from a situation of neither peace nor war. As Kalyvas and others have argued, it is the interaction of such factors, and not their individual, serial correlation with civil violence, that forms the basis for a causal explanation.

Third, while the political and economic factors just mentioned can fit alongside models such as Collier's (as in the two volumes of case studies edited by Collier and Sambanis ${ }^{13}$ ), there are others that simply cannot. In her study of peasant insurgency in El Salvador, Wood identifies motivations like participation, defiance, and pleasure in agency. In my own book, there is a chapter on the politics of ressentiment, and the play-like framing of much political violence in Côte d'Ivoire that allows participants to disavow moral responsibility at the same time that they can derive considerable enjoyment from destroying property and accosting others. ${ }^{14}$ Not only are such dynamics not quantifiable, they challenge the underlying assumptions of large-N studies such as Collier's, which must be built on the implicit foundation of actors who operate according to a shared rationality. The emotive and even perverse dynamics that micro studies tend to point out suggests that participants in violent politics are operating according to rational and irrational choice models at once. Such "irrational choice" models must account for the presence and significance of actors' desires for respect, honor, adulation, and revenge.

Fourth, there is a need for a much greater attention to non-elite actors than one finds in Collier's accounts. Who makes up the audience for elite political decisions, and what kinds of agency do midlevel bureaucrats, unemployed youth, rich and poor peasants, immigrant workers, and various other categories of non-elites exert? In Collier's depiction, we end up with two groups only-young men with guns, and the elite older men who lead, organize, fund, and instrumentalize them. Women are virtually absent. Again, terrorist violence is one example that poses the question of how violent actors rely on, recruit the sympathies of, and interact with the nonviolent majority. The Maoist canard of insurgents acting like fish in the sea of supportive peasants often obscures more than it reveals, at least in situations like the West African insurgencies I know best. In such settings, civilians may become the targets of grotesque violence (as Collier notes), while in other settings in the same country, relations may be cooperative and lacking in coercive violence. Political scientists including Kalyvas, Wood, and Jeremy Weinstein have taken different approaches to explaining such subnational variation, just as numerous anthropologists have explored the micropolitics that explain such dynamics. ${ }^{15}$ The difference here is more than the one between "lumpers" and "splitters," as some might suggest, thus demoting the significance of the distinction. It involves nothing less than "the ontology of political violence," to borrow Kalyvas's phrase. ${ }^{16}$ Indeed, in the West African setting (the same seems to be true in Central Africa and possibly the Middle East), such variations cross borders along with combatants, ethnic or religious groups, and politicaleconomic networks, thus blurring the lines that ostensibly distinguish the subnational, national, and international as units of analysis.

\section{Scientific Mystique and Policy in Africa}

In the political science literature I have cited as exemplary, the quest for analytical rigor thus begins with a considered selection of the units and categories of analysis that grows out of painstaking attention to history and sociocultural context. Collier brings his creativity and virtuosity to his selection of categories of analysis, eschewing the actors' own categories and stated intentions, "tainted" as they may well be with ideology, self-deception, or the desire to portray oneself in a positive light. These are, however, human beings. There are no true control groups, least of all in the context of war or the daily scramble for survival that characterizes the lives of the very poor. In this context of myriad relevant variables, extreme fluidity, and limited information, much of the intellectual heavy lifting in economic analyses of culturally different settings such as Africa is anecdotal, sometimes internally contradictory, and often highly questionable. It may reflect the author's own imagination of poor people's lives more than the realities of those lives. If these analyses are fundamentally flawed in this way, what is their staying power? Development economics as a discipline has been systematically unsuccessful in producing desired policy results, at least in the countries where the bottom billion reside. Moreover, those countries such as China and India that Collier hails as truly and rapidly developing have been characterized to a large extent by their rejection of the ministrations of such institutions as the World Bank.

I have focused mainly on The Bottom Billion so far, and on my reservations regarding the kinds of claims to knowledge that Collier makes, as well as some of the subtle sleights of hand he enacts in moving his argument forward. In his 2009 book, Wars, Guns, and Votes, Collier picks up where he left off, diving into an analysis of politics in the countries where the world's poorest billion people live. At this point, arguments that were questionable but insightful veer off into the factually incorrect, analytically upside-down, and politically dangerous.

It so happens that the most elaborated case study offered by Collier in Wars, Guns, and Votes is that of Côte d'Ivoire. A significant portion of my own research is about Côte d'Ivoire, and I have a book about to be published on the 
Ivorian conflict. It is a complex political, economic, and diplomatic series of events, and there are certainly numerous divergent possible interpretations. I hesitate to launch fully into a critique of Collier's chapter on the Ivorian conflict, both for fear of seeming mean spirited, and of seeming to promote my own work, but the disregard he shows here for the facts of the case indicate a lack of interest, even a contempt, for the particularities of actually existing African politics that I think should serve as a warning against Collier's dispensing political advice on the subject. Though he writes that "you can rest assured that droves of academics on the make are hacking away at the propositions in this book. And, of course, being scared to death of them, I have done my best to protect myself by eliminating the errors" (WGV: p. 235), this evidently did not apply to chapter 7, "Meltdown in Côte d'Ivoire." I will not belabor the point here, but there are basic factual errors about who did what to whom in almost every paragraph of the chapter from the point where he begins to analyze the cascade of events that began with the country's 1999 coup d'état. Of these, two bear special mention.

First, Collier gets many of the actors backward in his description of the period from the October 2000 elections to the March 2007 Ouagadougou accords. ${ }^{17}$ His misunderstanding of the balance of force in Ivorian politics causes him to claim that the 2002 coup attempt turned rebellion pitted the army against civilian militias who backed the "calamitously" elected Laurent Gbagbo. ${ }^{18}$ In fact, it was fought by one group of cashiered soldiers against the rest of the security forces, who were by then split more or less evenly between politically neutral soldiers and those dedicated to keeping Gbagbo in power. Militias joined the professional soldiers on both sides.

At the same time that he mangles the narrative of how power, ethnicity, and violence interacted (his ostensible interest in this case) on the domestic scene, he also misunderstands the role of various international players. He begins by suggesting that Gbagbo was able to gain French support for his illegitimate election by using "his party connections with the French socialist government," when in 2000 the French president was conservative Jacques Chirac. ${ }^{19}$ The crux of the issue was rather France's cynical decision to support "the devil they knew," rather than risk the unrest that might accompany a fresh election. The other main actor in this disastrous decision was the Economic Community of West African States (ECOWAS), the subregional body that played a major role throughout the Ivorian conflict, though it is hardly mentioned by Collier. From another angle, Collier misconstrues Liberia's central role in the rebellion from its first weeks. Liberian President Charles Taylor saw an opportunity to export civil war to yet another neighbor. The Liberians fighting in Côte d'Ivoire were thus not simply "Mercenaries ... hired on a 'pay yourself' basis'" (WGV: p. 164), but part of Taylor's strategy to achieve regional hegemony.
Another distortion of Collier's account of the international dimensions of the conflict comes in his overly positive description of the French peacekeeping force. He does not mention ECOWAS peacekeepers, who arrived shortly after the conflict began and were later "bluehatted" by the UN peacekeeping mission. The balance sheet of the French peacekeepers has been mitigated at best. Though Collier portrays the French as preventing a stronger Forces Nouvelles from overrunning Gbagbo's forces, the reality was far more ambiguous. Neither side was strong enough to dominate the other, and both blamed the French for aiding their adversary. The so-called zone of confidence buffer zone the French patrolled became the most dangerous place in the country, with numerous massacres and rapes taking place there. French peacekeepers also opened fire on Ivorians in the tense days of November, 2004, killing between twenty and sixty civilians. Gbagbo was undoubtedly cynical and committed to maintaining his grip on power at all costs, but Collier's description of him, denouncing the French to mass rallies of his youth supporters "and indeed inciting youth to kill French civilians in Abidjan," (WGV: p. 163) is to my knowledge pure fiction. Gbagbo is too skilled a tactician to open himself to the disapprobation that would bring. ${ }^{20}$ In sum, Collier takes a situation where there are no good guys, and turns the French into selfless heroes, trying to save the Ivorians from themselves. No French diplomatic or academic specialist on Africa I know would support this version of events, let alone any West Africans. I can only surmise that it is meant to set up the third part of the book, where Collier proposes his solutions to situations like Côte d'Ivoire's.

This chapter is puzzling inasmuch as it seems to betray a disregard for the empirics of a case that he holds up as exemplary of the dynamics he wants to understand and rectify. When he writes that Prime Minister Guillaume Soro "narrowly escaped death in a helicopter accident" (WGV: p. 166) -whereas he was actually in the state jet on the runway in Bouaké when someone shot a rocketpropelled grenade into the plane, killing two men sitting in the next row of seats-I wonder why no one factchecked the chapter. Moreover, I wonder what the status of such a chapter is, given the copious evidence of haste, and of a kind of impatience with the details of actual politics that could only render the elegance of the model Collier presents less clear. Told as a kind of yarn, in undeniably engaging, if somewhat flippant, prose, it reads like a story told among friends, imperfectly remembered from another telling by another raconteur. It thus bridges the quantitatively driven chapters in the first third of the book, adding a kind of emotive force to them, and setting up the final policy recommendations.

In the final third of Wars, Guns, and Votes, Collier makes his boldest policy recommendations yet. The states of the bottom billion, he argues, fail to provide their 
populations accountability or security. Moreover, given the structural relations that ensure that most of them can't or won't provide these public goods, it is up to international actors to impose them. According to Collier's pithy formulation, the countries in the bottom billion are "too large to be nations yet too small to be states" (WGV: p. 229). Small African states (especially the landlocked ones) need to sacrifice some of their sovereignty to garner the economies of scale they could derive from acting as the European Union or the fifty United States have done. $\mathrm{He}$ argues this point convincingly, but far less convincing is his quick jump to the assertion that African states (by this point in the book he has mostly given up the pretense of the bottom billion and refers consistently to Africa and its problems) will not cede any sovereignty, and so have to have both security and accountability provided from outside the continent.

Here, his pessimism about Africa's ability to gain economies of scale in providing security seems directly linked to some of his misreadings of the Ivorian situation. As I mentioned above, Collier makes no mention of ECOWAS's role in peacekeeping. However, over the course of peacekeeping operations in Liberia (twice), Sierra Leone, Guinea Bissau, and Côte d'Ivoire, ECOWAS has evolved into the most sophisticated peace imposition and one of the best peacekeeping institutions in the world. Its Nigerian, Ghanaian, Senegalese, and other West African soldiers have committed abuses and failed to protect civilians, but I would argue that they have done as well as NATO forces in the Balkans and far better than many of the South Asian battalions in various UN peacekeeping operations. The organization has learned from past mistakes and, most importantly, has come to value proactive diplomatic and political demarches as a means of avoiding the expenditure of lives and money to contain conflicts once they have begun. Clearly, ECOWAS agrees with Collier's findings that civil war is development in reverse, and that wars beget wars.

As he has argued that wars beget wars, Collier has also argued that coups beget coups, and have much the same deleterious effects on the economies and the political environments of the bottom billion countries. Thus it comes as a genuine shock that his final recommendation in WGV is that the way to coerce bottom billion countries into holding credible elections and respecting their outcomes is to create a mechanism whereby poor democratizing countries can sign on to a charter where they promise to accept the verdicts of voters, and powerful international actors promise to squelch any coup that comes along. If the leaders of the poor country renege and steal an election, then the internationals say all bets are off, giving a nudge and a wink to the country's military and effectively inviting them to stage a coup. This proposal can appear bizarre since Collier has not only shown that coups spawn more coups and a downward economic spiral, but has also decried Western countries' fetishization of elections as a misleading proxy for democracy earlier in the book. Now rigged elections are the tripwire proposed for the rich countries to give the poor country in question the thumbs up or thumbs down that might plunge the country into the very kinds of intractable conflicts Collier has been working to prevent? Perhaps he believes that no country would sign on and then fail to follow through, for fear of the consequences. But what of those leaders who feel that if they have the military brass supporting them, they are consequently free to steal elections at will? That is not such a different scenario from the one prevailing in a lot of poor countries Collier seems to have in mind. And who will decide which elections have met the fateful threshold of acceptability? Rich and middle-income countries, from Ukraine to Thailand to the United States, have bitterly contested elections, and the recent second-round elections in Guinea look far more like those scenarios than like the nowpassé elections where the incumbent claims 99 percent of the vote and 100 percent voter turnout. Who gets to decide if they have been rigged, and whether the security guarantee should be called off as a punishment?

What Collier is really arguing is that poor multiethnic countries have trouble achieving durable economic growth. This is the part where he says that African countries are too big to be nations. Choosing to ignore the example of monoethnic Somalia, he entertains a fantasy that if the national boundaries mapped neatly onto ethnolinguistic ones, conflict would magically diminish and development would take off. But do poor multiethnic countries stay poor because they are multiethnic or because they are poor? Certainly, Bangladesh and Somalia are not nearly so heterogeneous as India or Mali. But how strong a causal factor is ethnicity? And how well does ethnicity account for counterfactual cases? We know that war tends to polarize identity and that even where there was a high degree of intercommunal cooperation and intermarriage, once wars begin, identities like ethnicity, religion, race, and nationality become salient as cycles of revenge, resentment, and demonization develop path-dependent rationales. But what of the poor multiethnic countries that don't experience war? What of Mali, Senegal, and Ghana? What of those countries in between, India or Guinea, that experience interethnic clashes, but manage them in such a way that they do not jump to the level of a more general conflagration? A full discussion of ethnicity would require an article in itself, ${ }^{21}$ but anthropologists and political scientists have shown that there are infinitely many ways to construct competitive difference, from villages to clans to caste, just as every definition of enmity implies a related definition of alliance. In many African settings, ethnicity is epiphenomenal to the political dynamics that offer the conditions of possibility for its instrumentalization. It is dismaying to see social scientists uncritically take up the 
language of ethnicity without subjecting it to the kinds of rigorous interrogation they apply to other concepts that have become naturalized within Euro-American common sense.

\section{Conclusion}

I wish Paul Collier had opened The Bottom Billion with a passage like "In this book, I will present some intriguing and counterintuitive correlations between poverty and a variety of social and political phenomena. I will add to these correlations some insights from thirty-five years of experience as a development economist that may begin to explain some of the correlations. Some day, we may have a good enough understanding of these causal links in specific countries to make useful policy interventions there." The intellectual modesty such claims suggest would have been more in line with the evidence actually on offer, and to my mind, no less impressive for that. Such modesty would certainly have undercut Collier's readiness to offer policy prescriptions for places that few academics can claim to really understand.

In this view, ethnographic nuance is neither a luxury nor the result of a kind of methodological altruism to be extended by the soft-hearted. It is, in purely positivist terms, the epistemological due diligence work required before one can talk meaningfully about other people's intentions, motivations, or desires. The risk in foregoing it is not simply that one might miss some of the local color of individual "cases." It is one of misrecognition. Analysis based on such misrecognition may mistake symptoms for causes, or two formally similar situations as being comparable despite their different etiologies. To extend the medical metaphor one step further, misdiagnosis is unfortunate, but a flawed prescription based on such a misrecognition can be deadly. Policy interventions are already risky in the best circumstances.

A curious transference seems to have taken place within American universities, and Collier's work suggests that it exists to some extent in the UK, too. Many anthropologists have become increasingly interested in the ways that the political economy of globalization and neoliberal reforms have shaped local realities. Some of this work seems to have replaced the fine-grained analyses that emerge from long-term participant observer ethnographic research. An ungenerous estimation might be that too much cultural anthropology is indulging in half-baked economics. At the same time, I am struck by the extent to which economists, at least when they are writing about poor people in out of the way places, seem to rely on half-baked ethnographic insights, the kinds gleaned from corridor talk at meetings and by talking with taxi drivers on the way in from the airport and bartenders in business-class hotels. Surely neither group would recognize themselves in my description, but perhaps it says something about a kind of mutual attraction that dares not speak its own name. These differences between economics and anthropology seem to me to map fairly directly onto the differences between quantitative and qualitative political science.

Some of the most interesting ethnography taking place today is coming out of political science. Lisa Wedeen's work on piety, chewing qat, and politics in Yemen, and Ruth Marshall's work on the role of charismatic religion in Nigerian politics are two excellent examples. ${ }^{22}$ Another piece of political science ethnography I have found incredibly powerful is Timothy Pachirat's work on an American slaughterhouse, ${ }^{23}$ which brings together analyses of the political economy of beef, the politics of immigrant labor, and the politics of vision. Works such as these suggest that there is important work to be done, first identifying perplexing correlations and then patiently teasing out explanations of the causal dynamics involved. ${ }^{24}$ While my own view from anthropology suggests that one productive division of labor would have economists identifying the surprising correlations in cross-cultural economic phenomena and anthropologists explaining them, political scientists may be able to do both parts of this process in house. The anthropological caveat is a simple one: In the move to explain causality, the common sense that allows us to decipher correlations in our own societies may betray us if we attempt to apply it where people have a very different sense of what is common.

\section{Notes}

1 Just as Wars, Guns, and Votes aims to resolve the problem of bad governance laid out in The Bottom Billion, Collier's 2010 book, The Plundered Planet: Why We Must-and How We Can-Manage Nature for Global Prosperity, aims to solve the seemingly intractable problem of the natural resource trap.

2 Levitt and Dubner 2009; Moyo 2009.

3 Latour 1997.

4 Ferguson 2007.

5 Hacking 1990; Hacking (1975) 2006; Porter 1996. The term "low sciences" is Hacking's from The Emergence of Probability ([1975] 2006), where he describes how statistics emerged in the seventeenth century as a means of argumentation in such fields as alchemy and medicine. Developing natural sciences such as astronomy and mechanics chose demonstration as their preferred form of argumentation.

6 Rostow (1960) 1991.

7 Collier's rather stark distinction between national armies and rebel forces from the passage above seems to belie such a bias. Examples such as Sierra Leone's "sobels" ("soldiers by day, rebels by night") suggest that in some African settings, the lines between the two kinds of fighting force are far less clear than they might be in richer countries. 
8 Human Rights Watch 2005; Kourouma 2000; Utas 2005.

9 The series of case studies in Collier and Sambanis 2005 tend in this direction, though Collier and especially Sambanis make a valiant effort to maintain the viability of the Collier-Hoeffler model of civil war and the largely divergent case study materials.

10 Evans-Pritchard 1937.

11 Michael Bratton's essay (2009) on Robert Bates's When Things Fell Apart in this journal made a similar point.

12 Kalyvas 2006; Scott 2009; Wood 2003. Scott's delineation of the region of "Zomia," characterized by its geographic, sociological, and political characteristics, and making up a part of seven different nation-states, shows that such zones can be subnational and transnational at the same time. See also Tarrow 2007.

13 Collier and Sambanis 2005.

14 McGovern 2010.

15 Kalyvas 2006; Weinstein 2007; Wood 2003.

16 Kalyvas 2003.

17 He claims that when putschiste Robert Gueï attempted to steal the 2000 elections, it was the "Young Patriot" militias, financed by Blaise Compaoré, who fought the Ivorian security forces in the streets in order to put Gbagbo in power. In fact, after two days of spontaneous protests (by both Gbagbo's and Ouattara's supporters) against General Gueï, the Ivorian military, and particularly the gendarmes, turned against their erstwhile boss and helped to install Gbagbo. In the several days that followed, these members of the security forces joined with Gbagbo's youth supporters (who would not take on the name "Young Patriots" for another three years and who never received support from Compaoré) to oppose Ouattara's supporters in the streets. Ouattara's, like Bédié's supporters, were glad to see Gueï dispossessed of the rigged elections, but demanded that Gbagbo hold new ones open to all comers. When Ouattara's supporters killed a gendarme in one of these clashes, a group of gendarmes went on a rampage, killing fifty-seven putative "Northerners" and dumping them in a mass grave on the outskirts of Abidjan. Collier mistakenly attributes these deaths to the pro-Gbagbo militias.

18 The term “calamitous” was Gbagbo's own, describing the fact that most of the candidates for the presidency had been prevented from running by a constitutional court handpicked by Gueï for the purpose of preparing the way for his win. After losing the election, Guei still tried to claim victory, but was forced to stand down by two days of popular protests that caused most of the military to abandon his cause. From that point, most violence in the streets of Abidjan shifted its axis to pit the supporters of the excluded candidates (most especially northerner Alassane Ouattara), who called for fresh elections with all candidates standing, against the security forces, who now backed Gbagbo and were joined by pro-Gbagbo youths. Pro-Gbagbo youth militias would grow and become increasingly organized especially from 2003 to 2007, but were not yet called the "Young Patriots," as Collier claims.

19 Though this was a period of cohabitation with a socialist Parliament, Chirac controlled the country's foreign policy.

20 Indeed from even before the 2002 rebellion, Gbagbo was under threat from the French of prosecution by the International Criminal Court for war crimes. Gbagbo allowed his more vociferous acolytes like National Assembly president Mamadou Coulibaly, FPI party president Pascal Affi Nguessan, and Young Patriots leader Charles Blé Goudé do the threatening and incitement, but even the most violent speech was almost always veiled in a metaphorical language.

21 My book, McGovern 2010, attempts to unpack this topic in the context of the Ivorian conflict, typically portrayed as either an ethnically- or religiouslydriven conflict.

22 Wedeen 2008; Marshall 2009.

23 Pachirat forthcoming.

24 The two-volume World Bank publication Understanding Civil War (Collier and Sambanis 2005) does something like this, though the hierarchy of disciplines is very clear: the economists supplied the model (thus both correlation and causal explanation) and the ethnographers were tasked with testing and perhaps perfecting it. This is not the equal division of labor I have in mind.

\section{References}

Bratton, Michael. 2009. "Challenges to Democratization in Africa." Perspectives on Politics 7(2): 364-66.

Collier, Paul. 2010. The Plundered Planet: Why We Must-and How We Can-Manage Nature for Global Prosperity. New York: Oxford University Press.

Collier, Paul and Nicolas Sambanis, eds. 2005. Understanding Civil War: Evidence and Analysis. Washington: World Bank.

Evans-Pritchard, Edward. 1937. Witchcraft, Oracles and Magic among the Azande. Oxford: Clarendon Press.

Ferguson, Niall. 2007. "The Least Among Us.” New York Times (July 1).

Hacking, Ian. 1990. The Taming of Chance. Cambridge: Cambridge University Press. 
(1975) 2006. The Emergence of Probability: A Philosophical Study of Early Ideas about Probability Induction and Statistical Inference. Cambridge: Cambridge University Press.

Human Rights Watch. 2005. "Youth, Poverty and Blood: The Lethal Legacy of West Africa's Regional Warriors." New York: Human Rights Watch. URL: http://www.hrw.org/en/reports/2005/04/12/youthpoverty-and-blood, accessed 2 April 2011.

Kalyvas, Stathis. 2003. "The Ontology of "Political Violence': Action and Identity in Civil Wars." Perspectives on Politics 1(3): 475-94.

- 2006. The Logic of Violence in Civil War. Cambridge: Cambridge University Press.

Kourouma, Ahmadou. 2000. Allah n'est pas obligé. Paris: Seuil.

Latour, Bruno. 1997. "A Few Steps toward an Anthropology of the Iconoclastic Gesture." Science in Context 10(1): 63-83.

Levitt, Steven and Stephen Dubner. 2009. Freakonomics: A Rogue Economist Explores the Hidden Side of Everything. New York: Harper Perennial.

Marshall, Ruth. 2009. Political Spiritualities: The Pentecostal Revolution in Nigeria. Chicago: University of Chicago Press.

McGovern, Mike. 2010. Making War in Côte d'Ivoire. Chicago: University of Chicago Press.

Moyo, Dambisa. 2009. Dead Aid: Why Aid Is Not Working and How There Is a Better Way for Africa. New York: Farar, Strauss, Giroux.
Pachirat, Timothy. Forthcoming. Killing Work: Industrialized Slaughter and the Politics of Sight. New Haven, CT: Yale University Press.

Porter, Theodore. 1996. Trust in Numbers: The Pursuit of Objectivity in Science and Public Life. Princeton, NJ: Princeton University Press.

Rostow, Walter. (1960) 1991. The Stages of Economic Growth: A Non-Communist Manifesto. Cambridge: Cambridge University Press.

Scott, James. 2009. The Art of Not Being Governed: An Anarchist History of Upland Southeast Asia. New Haven, CT: Yale University Press.

Tarrow, Sidney. 2007. "Inside Insurgencies: Politics and Violence in an Age of Civil War." Perspectives on Politics 5(3): 587-600.

Utas, Mats. 2005. "Victimcy, Girlfriending, Soldiering: Tactic Agency in a Young Woman's Social Navigation of the Liberian War Zone." Anthropological Quarterly 78 (2): 403-430.

Wedeen, Lisa. 2008. Peripheral Visions: Publics, Power, and Performance in Yemen. Chicago: University of Chicago Press.

Weinstein, Jeremy. 2007. Inside Rebellion: The Politics of Insurgent Violence. Cambridge: Cambridge University Press.

Wood, Elisabeth. 2003. Insurgent Collective Action and Civil War in El Salvador. Cambridge: Cambridge University Press. 